\title{
Юлія Голубнича
}

\section{РЕПАТРІАЦІЯ ІНТЕРНОВАНИХ ВОЯКІВ АРМІЇ УНР 3 ПОЛЬЩІ (1921-1922 рр.): ПРИЧИНИ ТА НАСЛІДКИ}

\begin{abstract}
У статті розглянуто проблему репатріації інтернованих вояків Армії УНР з таборів Польщі в 1921-1922 рр. Наведено статистичні дані, розкрито умови повернення репатріантів на батьківщину. Проаналізовано вплив зовнішніх та внутрішніх чинників на перебіг репатріації.
\end{abstract}

Ключові слова: інтерновані, Армія УНР, Російсько-українська делегація, репатріачія, амністія.

Обставини перебування інтернованої у таборах Польщі Армії УНР у 1921-1924 pр. активно вивчались кількома дослідниками у другій половині 1990-х років, у т. ч. І.В. Срібняком, M.I. Павленком. Проте ці науковці не приділили достатньо уваги висвітленню процесу репатріації, значною мірою лише окресливши цю дослідницьку проблему.

3 підписанням у 1921 р. Ризького мирного договору між представниками РРФСР і УСРР з однієї сторони та Речі Посполитої з іншої постало питання репатріації українських та російських інтернованих вояків, колишніх полонених, біженців та інших категорій осіб. При цьому особлива увага приділялась інтернованому вояцтву Армії УНР, яке зберігало свою військову організацію в польських таборах.

Організацією репатріації інтернованих українців у Польщі займалася Російсько-українська делегація Мішаної радянсько-польської комісії, до функцій якої також належало й визначення порядку повернення додому російських полонених та біженців. На перших порах агітацію за повернення в Україну здійснювали військовополонені червоноармійці в тих таборах, де вони перебували разом із інтернованими вояками Армії УНР (Вадовиці, Стржалково). Тому для заохочення масової репатріації «колишніх чинів білих армій» потрібна була офіційна радянська амністія, на чому й наголошувала Російськоукраїнська делегація у своїх посланнях до НКЗС РСФРР і УСРР.

На офіційному ж рівні у поглядах на цю репатріацію відбулися певні зрушення в період мирних переговорів у Ризі. В Угоді про репатріацію не планувалося повернення в Україну і Росію союзних Польщі військових угруповань С. Петлюри, Ст. Булак-Балаховича, Б. Перемикіна та ін., хоча вже було окреслено поняття «інтернований». Йшлося про тих, хто «утримувався в ув'язненні, під арештом чи адміністративним наглядом». Щодо них, то в день підписання Угоди 24 лютого
1921 р. було ухвалено спеціальне доповнення так звана нота Домбського - Йоффе.

Згідно 3 нею в Україну і Росію мали право повертатись i представники вищеперелічених військових сил за умови припинення антибільшовицької діяльності та їх амністії радянською владою. Ця нота давала певну надію для частини вояцтва на повернення до рідних домівок. Вже у червні 1921 р. Департамент політичної інформації МВС УНР (який виконував функції розвідки і контррозвідки в екзилі) доповідав Головній команді військ УНР про пожвавлення в урядових структурах Державного центру УНР і в таборах інтернованої Армії УНР комуністичної агітації за виїзд до радянської України для відбудови там економічного і політичного життя ${ }^{1}$. Одним із наслідків цієї підривної кампанії стало збільшення відсотка дезертирів з таборів вже з наступного місяця, причому це були не лише козаки, а й деякі старшини.

Українське командування таборів та вищий політичний провід УНР намагались (за мовчазної згоди польських комендатур) запобігти цьому деструктивному процесу та в різний спосіб перешкодити від'ізду загітованих більшовиками інтернованих додому. Про це повідомляв голова Російсько-української делегації Мішаної коміciї Ю. Ігнатов міністра закордонних справ Речі Посполитої Польської Я. Домбського.

Радянська влада до осені 1921 р. ще не виробила конкретної тактики щодо інтернованих. Одне було незаперечним - у неї не викликала сумніву потреба у ліквідації таборів, що давали змогу зберегти боєздатні антибільшовицькі військові формування. Посол Росії у Польщі Л. Карах для цього використовував найефективніший тиск - економічний. Радянський дипломат заявляв Я. Домбському: «Поки хоч один петлюрівець буде у таборі, поляки не одержать

1 ЦДАВО України. - Ф. 2439. - Оп. 1. - Спр. 69. Арк. 3. 
50 млн крб золотом, що повинні бути їм видані згідно Ризького трактату»².

Стосовно подальшої долі українських вояків після ліквідації таборів у радянської сторони існували різні думки. Українські представники Російсько-української делегації у Варашаві (Наум Калюжий, а згодом Василь Христов) пропонували репатріювати основну масу інтернованих в Україну і таким чином знешкодити цю військову силу, яка все ще була налаштована проти більшовизму. Водночас голова української частини Мішаної польсько-російсько-української комісії (з осідком у Харкові) А. Глінський пропонував їх не приймати. Його мотивацією була не стільки непідготовленість фільтрації «петлюрівців» 3 метою «виявлення шкідливих елементів», як посилення за рахунок даного контингенту «місцевих петлюрівських банд». Але врешті-решт перемогли адепти першої позиції.

У 1921 р. Уряд УНР в екзилі прагнув реваншу і готував антибільшовицьке збройне повстання в Україні. Його повинні були ініціювати вояки Армії УНР, які залишилися в Україні, місцеві партизанські загони та військові підрозділи, сформовані з інтернованих. Але низький рівень готовності населення до повстання, незадовільне матеріальне забезпечення військових з'єднань, які діяли на теренах України і які перейшли із території Польщі, а також відсутність масової підтримки місцевим населенням, поінформованість більшовиків стосовно маршрутів, кількості військових угруповань та якості озброєння стали безпосередніми причинами поразки Другого зимового походу під проводом генерала Ю. Тютюнника у листопаді 1921 р.

Уряд УСРР розумів, що невдала спроба повалення радянської влади не вгамує бажання української еміграції знову використати зручну можливість для повстання. Адже остання продовжувала зберігати певний військовий потенціал. Щоб унеможливити проведення вояками Армії УНР партизанських рейдів до УСРР, іï дипломатичне представництво у Речі Посполитій Польській домагалося укладення спеціальної конвенції про взаємну видачу карних злочинців, до категорії яких перш за все відносили вояків Армії УНР.

Певним компромісом стала умова репатріації інтернованих на основі ноти Домбського Йоффе. Щоправда, на початку 1922 р. заключна частина тексту амністії ВУЦВК була опублікована багатьма засобами масової інформації і навіть весь текст амністії був розповсюджений у табо$\operatorname{pax}^{3}$.

Розробкою інструкції стосовно проведення репатріації займалася спеціально створена для

\footnotetext{
2 ЦДАВО України. - Ф. 1075. - Оп. 2. - Спр. 474. Арк. 226.

3 Там само. - Ф. 4. - Оп. 1. - Спр. 825. - Арк. 102.
}

цього комісія Варшавської Мішаної комісії. Польська делегація зобов'язувалася надати цій підкомісії необхідні відомості щодо місця перебування інтернованих та їх кількісного складу. Причому військові, які входили в робітничі партії, але бажали виїхати в Росію чи Україну, повинні були повернутися до таборів. У табори інтернованих мали бути відряджені уповноважені підкомісії для виявлення бажаючих повернутися на батьківщину. Передбачалося, що ті, хто погодився репатріюватися, мали бути відділені від решти інтернованих і засвідчити своє рішення у письмовій формі. Після цього вони отримували право спілкуватися наодинці з уповноваженими. Транспортні списки складалися на основі заяв самих репатріантів ${ }^{4}$.

Крім того, Російсько-українська делегація могла реєструвати потенційних репатріантів у Варшаві (у місті осідку) та в Рівному й Барановичах (де розташовувалися іiї експозитури). Досить детально була розроблена процедура оформлення документів репатріантів та їх відправлення. Оскілки коштів на виготовлення фотокарток для всіх репатріантів не вистачало, то часто їх замінювали відбитками пальців. До анкет додавалися свідчення в лояльності щодо радянської влади. Анкети реєструвалися в книзі обліку, на кожній $з$ яких ставився порядковий номер. Два ії примірники із засвідченням у лояльності відправлялися в НКЗС УСРР, третій відсилався з транспортом разом із загальною та індивідуальною характеристикою. У міру можливості транспорт супроводжували коменданти та інформатори. Усі ці заходи мали запобігти проникненню в УСРР ворожих елементів ${ }^{5}$.

Кошти на репатріацію військових колишніх «білих» армій у сумі 16 млн п. м. надала Росія, хоча зі свого боку Російсько-українська делегація і просила уряд УСРР видати для цієї мети 2 млн п. м. ${ }^{6}$ Частина коштів, наданих урядом УСРР для репатріації радянських військовополонених (17 млн 600 тис. п. м.), була витрачена й на репатріантів - «петлюріців». Із 20 тис. комплектів обмундирування, закуплених на ці гроші, залишилося невикористаними 2 тис., які Російськоукраїнська делегація відправила до пересильного пункту в Рівному і роздала колишнім воякам Армії УНР 7 .

Слід зазначити, що ВУЦВК відносив репатріантів - колишніх бійців Армії УНР - до категорії біженців ${ }^{8}$. А «українська біла армія», за спостереженнями і розрахунками Російсько-української делегації, розшарувалася на три частини. Ї̈і ядро

\footnotetext{
4 Там само. - Спр. 823. - Арк. 1.

5 Там само. - Спр. 826. - Арк. 69-71.

6 Там само. - Спр. 825. - Арк. 104.

7 Там само. - Спр. 826. - Арк. 210.

8 Там само. - Спр. 826. - Арк. 19.
} 
(третина особового і командного складу) утворювали національно свідомі елементи. Значну частину становили приєднані пізніше до них члени різних повстанських загонів, які воювали проти більшовиків, та громадяни, призвані свого часу на службу Директорією УНР, чи вояки, які були мобілізовані А. Денікіним і згодом перейшли до Армії УНР. Ця частина українського війська була менш політично стійка. До третьої частини відносились колишні червоноармійці, які потрапили у полон у період польсько-радянської війни і погодились поповнити Армії УНР.

Незадовільні результати репатріації українських вояків (зголосилось 18 осіб) змусили представників Мішаної польсько-радянської комісії у Стржалково прийняти 20 березня 1922 р. постанову про необхідність проведення у таборах персонального опитування щодо використання можливості повернутись додому ${ }^{9}$. Але на тому етапі інспектор таборів Дзержинський відмовився виконати цю постанову, аби не ображати уповноважених і не збурювати мешканців таборів.

На рішення Дзержинського певною мірою вплинула і реакція Головної команди Армії УНР. Вона протестувала не лише проти персонального опитування інтернованих, а й узагалі проти оголошення радянської амністії в таборах. Її мотивацією було те, що більшовицький режим є окупаційним для України, очолюваний до того ж іноземцем Х. Раковським, а оголошена ним амністія розцінювалась як образа для українців. Більше того, С. Петлюра розцінив дозвіл польських владних структур Російсько-української делегації провести репатріацію в середовищі українського вояцтва як порушення взятих польською владою зобов'язань щодо інтернованих, ігнорування вимог права «азилю» і міжнародної етики й, зрештою, «формування психологічно-політичних моментів, невідповідаючих інтересам майбутнього співжиття України та Польщі перед обличчям подій, що мають постати на терені колишньої Росії». Головний Отаман наголошував, що кроки польського Міністерства закордонних справ у цій справі $є$ продовженням політики ліквідації таборів, яку воно послідовно здійснює після укладання Ризького договору ${ }^{10}$.

Невдача у таборі Стржалково не зупинила репатріаційної діяльності Російсько-української делегації. Тиск на польську владу мав певні результати. У калішському і щепіорнському таборах було дозволено прочитати тексти амністії окремо старшинам і козакам. 28 березня іiї оприлюднили

9 Срібняк І.В. Обеззброєна, але нескорена: Інтернована Армія УНР у таборах Польщі й Румунії (1921-1924рр.) / І.В. Срібняк. - Київ - Філядельфія, 1997. - С. 44.

10 ЦДАВО України. - Ф. 1075. - Оп. 2. - Спр. 827. Арк. 404. в Каліші і 1 квітня - в Щипіорно ${ }^{11}$. У результаті, як доповів своєму керівництву голова Російськоукраїнської делегації О. Аболтін, на виїзд записалося близько 150 осіб. Загалом із калішського i щипіорнського таборів було репатрійовано близько 100 осіб, причому переважно уродженців російських губерній ${ }^{12}$.

Незадоволена фактичним провалом своєї місії Російсько-українська делегація наполягала на втіленні рішення Мішаної польсько-радянської комісії від 20 березня 1922 р. стосовно персонального опитування про репатріацію, мотивуючи свої вимоги нерішучістю і несміливістю інтернованих висловити своє волевиявлення. Міністерство закордонних справ Речі Посполитої Польської було вимушене зробити їй поступку і засвідчити цю постанову.

Мешканців кожного бараку опитували окремо. Спочатку, вишикувавши таборян у ряд, їх ознайомили 3 процедурою опитування. Потім інтерновані підходили до представників радянської сторони і стисло відповідали «бажаю» чи «не бажаю» репатріюватися. Тут же перебували і представники Російсько-української делегації, таборової польської адміністрації та української команди. Осіб, які виявили бажання репатріюватися, мали записати уповноважені Російськоукраїнської делегації. Ці інтерновані, забравши речі у бараці, направлялися в окремий сектор для очікування виїзду.

Але i такі заходи, на думку Російськоукраїнської делегації, не розвіювали побоювань потенційних репатріантів перед можливим їх покаранням більш стійкими товаришами по зброї. Не маючи гарантії від таких ексцесів, Російсько-українська делегація залишила табір і невдовзі почала вимагати від польської адміністрації табору створення сприятливіших умов для діяльності їі представників ${ }^{13}$.

У своєму звіті до НКЗС РСФРР і УСРР Російсько-українська делегація намагалася відвертіше подати причини своєї невдалої спроби організувати виїзд вояків на батьківщину. Насамперед до Варшави у представництво делегації та Посольство УСРР за іiі висновками прибували окремі інтерновані чи їхні представники 3 проханнями дозволити їм виїзд в Україну. Проте зимовий варіант репатріації не був організований, оскільки це питання було лише на рівні

11 Павленко M.I. Українські військовополонені й інтерновані у таборах Польщі, Чехословаччини та Румунії: ставлення влади і умови перебування (1919-1924 рр.) / М.I. Павленко. - К., 1999. - С. 157.

12 ЦДАВО України. - Ф. 1078. - Оп. 2. - Спр. 207. Арк. 30.

13 Павленко M.I. Українські військовополонені й інтерновані у таборах Польщі, Чехословаччини та Румунії: ставлення влади і умови перебування (1919-1924 рр.) / M.І. Павленко. - К., 1999. - С. 158. 
обговорення. Процедура зачитування амністії 3 метою виявлення потенційних репатріантів під час весняного об'ізду таборів також не сприяла успішному завершенню цієї місії.

Основні причини провалу члени місії конкретно не називали, але засвідчували у своїх звітах: «Табори колишніх чинів російської білої армії різко відрізняються від упорядження таборів колишніх чинів української білої армії. Останні являють собою військові частини, які ще цілком збереглися, тісно спаяні єдиним командуванням, чого нема у російських білих арміях. В українських таборах до цього часу знаходиться на своїх місцях як вищий, так і нижчий командній склад, при військових частинах діє контррозвідка, щоденно видаються накази по групі, збереглися свої відділи постачання... При частинах знаходяться свої культурно-освітні органи, котрі навіть видають газети» 14 .

Російсько-українська делегація також зазначала, що стан бойової підготовки українських і російських підрозділів відігравав важливу роль у ставленні до них польських військових властей. «Через сильний розклад у середовищі російських інтернованих польський уряд особливо не зацікавлений у їх залишенні на своїй території, за винятком свідомих білогвардійців, у завдання яких входить як вербування прикордонних банд, так і шпигунство у Росії. Що стосується колишніх петлюрівців, то в їх залишенні польська влада зацікавлена, їх розглядають як сформовані бойові одиниці, які будь-якої миті можуть бути використані», - зазначалося у звіті ${ }^{15}$.

Для заохочення українських вояків повернутися в Україну Російсько-українська делегація пропонувала НКЗС УСРР організувати урочисті зустрічі репатріантів на території України, а також їх висвітлення у пресі, надсилання схвальних листів репатріантів до таборів ${ }^{16}$.

Можливо, певна частина воїнів і погодилася 6 на репатріацію, але остерігалася гніву з боку українських таборових адміністрацій. За дописами Російсько-української делегації бажаючі повернутися в Україну трактувались як зрадники та піддавалися різним формам морального та фізичного впливу (побиттю, їх звинувачували у крадіжках, шпигунстві, саджали у карцер, інколи і до польської в'язниці). Навіть тих, хто зумів дістатися представництва Російсько-української делегації чи дипломатичного представництва УСРР і зареєструватися на виїзд, повертали до табору і саджали у карцер. Серед них траплялися і представники командного складу, які намагалися виїхати в УСРР завдяки персональним зверненням

14 ЦДАВО України. - Ф. 4. - Оп. 1. - Спр. 826. Арк. 75.

15 Там само. - Спр. 825. - Арк. 80.

16 Там само. - Спр. 826. - Арк. 110. (на них не поширювалась амністія). До таких вояків українське командування ставилося особливо прискіпливо. Адже цими намірами вони руйнували самі підвалини інтернованих українських військ. Але згодом незадовільний стан репатріації українських вояків змусив Російсько-українську делегацію пропонувати відповідним радянським структурам поширити амністію і на командний склад Армії УНР.

У результаті весняного опитування інтернованих у 1922 р. щодо їх можливої репатріації (згідно з даними Міністерства військових справ Речі Посполитої Польської, опублікованих польським дослідником 3. Карпусем) після оголошення амністії на виїзд згодилася 721 особа iз формувань С. Булак-Булаховича i тільки 30 українців 3 табору у Стржалкові й 93 3 табору в Каліші ${ }^{17}$.

Всього $з$ червня 1922 р. до 1 січня 1923 р. із Польщі до УСРР було повернено 2541 амністований, із них - 1408 вояків Армії УНР (149 старшин, 1261 козак), із Добровольчої армії - 439, із Руської армії - 52. Інші були із різних партизанських загонів, що перебували на території Польщі, та 117 репатріантів із Чехословаччини. За цей час було відмовлено у в їзді в Україну (на основі довідок губвідділів як ворожим елементам) 67 особам, із них - 57 цивільним і 10 амністованим $^{18}$.

Серед причин, що призвели до таких невтішних, на думку більшовиків, результатів, О. Аболтін називав інструкцію до амністії від 12 квітня 1922 р., яка дозволяла відправляти командний склад без запиту ВУЦВК. Він зазначав, що хоч перед самою поїздкою до таборів Російськоукраїнська делегація одержала телеграму НКЗС УСРР про дозвіл відправляти командний склад без запиту ВУЦВК, але про попередню інструкцію були вже оповіщені таборити. Тому навіть ті старшини, які надіслали у Варшаву свої анкети і заяви до розгляду, не записались при опитуванні, а залишилися чекати відповіді ВУЦВК ${ }^{19}$.

Також важливу роль відіграли і антирепатріаційні заходи українського командування. Це були звернення Головного Отамана до вояків, у яких містився заклик до «скупчення, обачності та вияву патріотизму і державної витримки, які були проявлені армією у березні під час приїзду

17 Павленко M.І. Українські військовополонені й інтерновані у таборах Польщі, Чехословаччини та Румуніі: ставлення влади і умови перебування (1919-1924 рр.) / М.I. Павленко. - К., 1999. - С. 160.

18 ЦДАВО України. - Ф. 4. - Оп. 1. - Спр. 15. Арк. 150.

19 Павленко М.І. Українські військовополонені й інтерновані у таборах Польщі, Чехословаччини та Румуніі: ставлення влади і умови перебування (1919-1924 рр.) / М.I. Павленко. - К., 1999. - С. 168. 
більшовицької делегації» ${ }^{20}$. Водночас розвінчувалася практика надсилання листів репатріантами. Крім того, аби зашкодити репатріації, найбільш ненадійні частини відсилалися на роботи за межі таборів. За даними Російсько-української делегації, на той час у робітничих партіях перебувало близько 5 тис. вояків Армії УНР.

Варто зазначити, що командний склад також противився репатріації. Зокрема, активно продовжували застосовуватися методи психологічного тиску, коли всіх бажаючих повернутися на батьківщину саджали у карцер і вони не могли ніде знайти захисту, оскільки нечисленна польська адміністрація підтримувала представників українського командування. Крім того, провід українських таборів під час репатріаційної діяльності Російсько-української делегації докладав усіх зусиль для покращення умов існування своїх підлеглих у таборах. Наприклад, перед приїздом делегації Мішаної комісії до Каліша та Щепіорно

${ }^{20}$ ЦДАВО України. - Ф. 4. - Оп. 1. - Спр. 826. Арк. 178. інтендантська служба забезпечила таборян білизною та теплим одягом. Натомість запідозрені у від'їді не отримали нічого, а у від'їжджаючих забирали теплі речі ${ }^{21}$. Сукупність усіх цих чинників значно обмежувала обсяги репатріації вояків Армії УНР.

Можна констатувати той факт, що вирішальну роль у репатріації вояків Армії УНР відіграла позиція Москви. Спершу вона стримувала цей процес, покладаючи сподівання на часткове знищення найактивнішої частини вояків. Коли стало зрозуміло, що таким способом загрозу не усунути, Москва дослухалась до позиції Харкова, який пропонував максимально вивезти інтернованих на території УСРР і встановити над ними контроль. Проте репатріація здійснювалась лише до кінця 1922 р., поки знову не була заборонена Москвою.

21 Павленко М.I. Українські військовополонені й інтерновані у таборах Польщі, Чехословаччини та Румунії: ставлення влади і умови перебування (1919-1924 рр.) / M.I. Павленко. - К., 1999. - С. 171.

\section{ДЖЕРЕЛА}

1. Павленко М.І. Українські військовополонені й інтерновані у таборах Польщі, Чехословаччини та Румунії: ставлення влади і умови перебування (1919-1924 pp.) / M.I. Павленко. — К., 1999. — $352 \mathrm{c}$.

2. Срібняк І.В. Обеззброєна, але нескорена: Інтернована Армія УНР у таборах Польщі й Румунії (1921-1924 рр.) / І.В. Срібняк. - Київ - Філядельфія, 1997. - 187 с.

3. Центральний державний архів вищих органів влади та управління України (далі - ЦДАВО України). - Ф. 4. - Оп. 1. - Спр. 15. - 343 арк.

4. ЦДАВО України. - Ф. 4. - Оп. 1. - Спр. 823. - 268 арк.

5. ЦДАВО України. - Ф. 4. - Оп. 1. - Спр. 825. - 346 арк.

6. ЦДАВО України. - Ф. 4. - Оп. 1. - Спр. 826. - 402 арк.

7. ЦДАВО України. - Ф. 1075. - Оп. 2. - Спр. 474. - 274 арк.

8. ЦДАВО України. - Ф. 1075. - Оп. 2. - Спр. 827. - 312 арк.

9. ЦДАВО України. - Ф. 1078. - Оп. 2. - Спр. 207. - 423 арк.

10. ЦДАВО України. - Ф. 2439. - Оп. 1. - Спр. 69. - 386 арк.

\section{REVERENCES}

1. Pavlenko M.I. Ukrayinski viyskovopoloneni i internovani u taborakh Polshchi, Chekhoslovachchyni ta Rumunii: stavlennia vlady i umovy perebuvannia (1919-1924 rr.) / M.I. Pavlenko. — K., 1999. — $352 \mathrm{~s}$.

2. Sribniak I.V. Obezzbroiena, ale neskorena: Internovana Armiia UNR u taborakh Polshchi i Rumunii (1921-1924 rr.) / I.V. Sribniak. — Kyiv — Filiadelfiia, 1997. — 187 s.

3. Tsentralnyi derzhavnyi arkhiv vyshchykh orhaniv vlady ta upravlinnia Ukrainy (dali - TsDAVO Ukrayiny). - F. 4. - Op. 1. - Spr. 15. - 343 ark.

4. TsDAVO Ukrayiny. - F. 4. - Op. 1. - Spr. 823. - 268 ark.

5. TsDAVO Ukrayiny. - F. 4. - Op. 1. - Spr. 825. - 346 ark.

6. TsDAVO Ukrayiny. - F. 4. - Op. 1. - Spr. 826. - 402 ark.

7. TsDAVO Ukrayiny. - F. 1075. - Op. 2. - Spr. 474. - 274 ark. 
8. TsDAVO Ukrayiny. - F. 1075. - Op. 2. - Spr. 827. - 312 ark.

9. TsDAVO Ukrayiny. - F. 1078. - Op. 2. - Spr. - 423 ark.

10. TsDAVO Ukrayiny. - F. 2439. - Op. 1. - Spr. 69. - 386 ark.

\section{Юлия Голубныча \\ РЕПАТРИАЦИЯ ИНТЕРНИРОВАННЫХ ВОИНОВ АРМИИ УНР ИЗ ПОЛЬШИ (1921-1922 гг.): ПРИЧИНЫ И СЛЕДСТВИЯ}

В статье рассмотрена проблема репатриации интернированных воинов Армии УНР из лагерей Польши в 1921-1922 г2. Приведены статистические данные, раскрыты условия возвращения репатриантов на родину. Проанализировано влияние внешних и внутренних факторов на ход репатриации.

Ключевые слова: интернированные, Армия УНР, Российско-украинская делегачия, репатриация, амнистия.

\section{Yuliia Holubnycha \\ THE PROBLEM OF REPATRIATION OF INTERNMENT UPR ARMY IN POLAND (1921-1922)}

With the signing in 1921 of the Treaty Peace of Riga between the RSFSR and the USSR on the one hand and the Polish Republic on the other, there was the problem of repatriation of Ukrainian and Russian prisoners of war, refugees and focused on the UPR Army interned. The problem of repatriation of Ukrainian internment in Poland was engaged in Russian-Ukrainian delegation. At first campaign for the return to Ukraine conducted military prisoners of war in those camps where they were interned together with soldiers UPR. So to encourage the mass repatriation it was necessary official Soviet amnesty, that was emphasized by the Russian-Ukrainian delegation in its letters to NKZS RSFSR and the Ukrainian SSR. The Agreement on repatriation was not scheduled to return to Ukraine and Russia still operating with Poland allied military groups of S. Petliura and others. Soviet authorities until autumn 1921 had not made specific tactics on internment. One thing was undeniable - it was no doubt a need for liquidation camps that allowed maintain combat-ready anti-Bolshevik military groups. A compromise was interned repatriation condition based on "Dabski - Joffe" treatment.

The development of instructions for carrying out the repatriation engaged specially created for this purpose committee of Mixed Soviet-Polish Comission. The Polish delegation undertook to provide this subcommittee relevant information on the location of the internees and their quantitative composition. In internment camps should be directed subcommittee authorized to identify those who wished to return home. It was assumed that those who agreed to repatriate, were separated from the rest of the mass internment and confirmed their decision in writing. Russian-Ukrainian delegation also stressed that the combat training of the Ukrainian and Russian forces played an important role in attitude Polish military authorities towards them. The Polish government was interested in preserving Ukrainian units.

Also an important role in the process of failed repatriation played anti-repatriation activities of the Ukrainian command. It was an appeal of the Chief Ataman to soldiers. It should be noted that the command staff was opposed to repatriation. So hard the combination of these factors greatly hampered mass repatriation of military UPR Army.

Key words: internees, UPR Army, Russian-Ukrainian delegation, repatriation, amnesty. 